\title{
Attributes of bioactive compounds isolated from commercial brands of fenugreek (Trigonella foneum-graecum) in relation to organic solvent systems and their potential as antioxidants and biological activity
}

\author{
Tahir Mehmood ${ }^{1 *}$, Maria Ahmed ${ }^{1}$, Zahra Jabeen ${ }^{2}$, Abdul Karim¹, \\ Muhammad Ashraf Shaheen ${ }^{1}$ and Faiza Siddique ${ }^{1}$ \\ 1. Department of Chemistry, University of Sargodha, 40100 Sargodha-Pakistan \\ 2. Department of Biochemistry, Government College University, Faisalabad-38000-Pakistan \\ *Corresponding author's email: tahiruosbiochem@yahoo.com \\ Citation \\ Tahir Mehmood, Maria Ahmed, Zahra Jabeen, Abdul Karim, Muhammad Ashraf Shaheen and Faiza Siddique. \\ Attributes of bioactive compounds isolated from commercial brands of fenugreek (Trigonella foneum-graecum) in \\ relation to organic solvent systems and their potential as antioxidants and biological activity. Pure and Applied \\ Biology. Vol. 6, Issue 3, pp871-881. http://dx.doi.org/10.19045/bspab.2017.60092
}

Received: 02/05/2017

Revised: $16 / 07 / 2017$

Accepted: 19/07/2017

Online First: 21/07/2017

\section{Abstract}

The present study is about potential variations of bioactive compounds from different commercial brands of fenugreek; in relation to multiple organic solvent systems, antioxidants and antimicrobial assays. Total phenolic contents, total flavonoid contents, individual phenolic acids, and DPPH assays were checked whereas phenolics analysis was performed by HPLC spectrophotometrically. Antimicrobial activity of different extracts was ascertained by disc diffusion method. The crude extract yields for different commercial brands of fenugreek ranged from 35.53-62.77 g/100g dry weight. Maximum yield was obtained from $100 \%$ Local Fenugreek with methanol while minimum was obtained from $100 \%$ local fenugreek chloroform. A considerable amount of TPC and TFC 24.4- $42.60 \mathrm{mg}$ of Gallic acid equivalents per $\mathrm{g}$ of sample dry weight (mg GAE/g DW) and 0.75-1.87 as $\mathrm{mg}$ of catechin equivalents per gram of sample dry weight (mg CE/g DW) respectively was observed. The amount of DPPH and reducing power essay was $0.927-3.78 \mathrm{mg} / \mathrm{mL}$ and $4.20-7.76 \mathrm{mg} / \mathrm{mL}$ respectively. Different brands of fenugreek had significant amount of phenolics acids ranging from 14.36-1035.44 mg/kg, where Gallic acid was found in all extracts. Antimicrobial activity was tested against microorganisms and were found to be considerable significant. These finding indicates that fenugreek has strong potential to be used as pharmaceuticals, antioxidants and preservatives.

Keywords: Antioxidant activity; Biological activity; Extraction efficacy of solvents; Total phenolics;

Total flavonoids

Introduction

Lots of changes have been observed in modern civilization which, no doubt provide many significant benefits but on other hand, has brought a greater risk to human life, for instance use of chemicals, pesticides, 
environmental pollutants, and others cause increased level of free radical production in the body. In living organisms oxidation reactions produced by free radicals cause the oxidation of bio-molecules like lipid, DNA, RNA and protein etc $[1,2]$. Whereas the food issues are concerned, the shelf life of the fresh and processed food decreases by oxidative reactions. Thus, the human health is affected due to toxicity from the environmental factors and also from the preserved food stuff [3]. Antioxidants have the ability to retard the damage by free radicals in biological systems as they capture or quench those free radicals that are involved in causing damage to human body and food. They are also very important in increasing the shelf life of food which is affected by oxidative reaction. Synthetic antioxidants are mostly used in food processing and pharmaceuticals industries, but they have many side effects such as liver damage and carcinogenic effect [4]. So, there is need to explore and isolate natural antioxidants in high amount, which have very fewer or no side effects and can be used in medicine instead of the synthetic antioxidants [5].

Plants and fruits are the most important, more safer and compatible sources of natural antioxidants. Epidemiological evidence in the literature have shown that the intake of natural products have been responsible for the lower prevalence of chronic diseases, for example, cancer and heart diseases. Natural products, in addition to the vitamins and minerals, contain phytochemicals such as flavonoids and other phenolics, which may exert therapeutic effects in human diseases [6]. Many phytochemicals possessed the antioxidant activity which helps to protect the cells against the oxidative damage caused by free radicals [7]. Despite, there is great interest in determining the role of phytonutrients, as the synthetic molecules have some side effects, and there is increasing trend for natural active compounds. In this scenario, beside nutritional value, functional foods have a potentially positive effect on the health [8, 9].

Trigonella foenum-graecum also called Fenugreek (locally known as Methi) is widely grown in Pakistan, India, Egypt, and Middle Eastern countries [10]. It belongs to the family Fabaceae. It often used as a condiment in Mediterranean countries and Indian sub-continental location. Fenugreek contains a gum or mucilage which is called galactomannan which acts as a thickener or stabilizer or additive in food [11]. Fenugreek (Trigonella foneum-graecum) is considered to be the oldest medicinal plant, and had been used as a tonic for treatment of edema of legs, lactation stimulant, in treatment of baldness, anti-diabetes and cholesterol reducing properties, as an antibacterial, antiinflammatory and antiulcerogenic [12]. Recent research has also shown that fenugreek helps in lowering the blood glucose level and plays a significant role for treatment of diabetes. Diabetic rats treated by supplementation of fenugreek seeds showed elevation in their antioxidant potential [13]. Fenugreek has a great role in pharmacological aspect that may include anti-inflammatory, antiviral, antitumor, hypertensive, anti-microbial and antioxidant activity [14].

The functional constituents in natural sources are affected by varieties, cultivation, maturation, storage, and processing. The nature of extracting solvent also plays an important role in resulting extracts yields for their antioxidant activities and other important bioactive compounds [15, 16]. Multiple solvents system plays a vital role in extraction of maximum bioactive compounds from selected plants it also avoids fruitless effort in future by avoiding solvent that extract minimum compound [17]. As fenugreek is reported to be rich 
source of valuable metabolites and antioxidants such as phenolic acid and flavonoids [18], it would be interesting to evaluate the extract, by using different solvents systems, from different commercial brands of fenugreek that includes shan, national and local verity for their different antioxidant attributes.

\section{Materials and methods}

\section{Sample collection}

Three different samples of fenugreek were collected. Two samples were marketed by shan and national while the third sample of fenugreek was bought from the local market.

\section{Preparation of extracts}

The samples were dried after cleaning, crushed into fine powder, placed separately in polythene bags and marked individually and then placed in refrigerator. Extraction of all samples was done by different solvents having different ratios e.g. 100\%, $80 \%$ and $50 \%$ methanol and chloroform. Ratio of sample plus solvent are kept as 1/10 (w/v). Extraction was done for 12 hours thrice by using orbital shakers. Extract was separated by the process of filtration by keeping residue left behind. These extracts were concentrated by using vacuum rotary evaporator at reduced temperature under vacuum. After that extract was kept in refrigerator at a temperature of $4{ }^{\circ} \mathrm{C}$ and then used for further analysis [19].

\section{Assessment of total phenolic contents (TPCs)}

Quantity of TPC was calculated using FC (Folin-Ciocalteu) reagent as described by Kalpna et al. [20]. The result expressed as GAE (gallic acid equivalents) $\mathrm{mg} / \mathrm{g}$ of dry weight of sample. Readings were taken in triplicate and the results were averaged. Results were reported on the basis of dry matter.

\section{Determination of total flavonoid contents (TFCs)}

TFCs were determined by the procedure followed by Zhishen et al. [21]. The results were expressed as catechin equivalent (10$500 \mathrm{ppm})\left(\mathrm{R}^{2}=0.9913\right) \mathrm{CE} \mathrm{mg} / \mathrm{g}$ of dry weight. Assay was performed in triplicate.

\section{Determination of reducing power (RP)}

The reducing power of CFPE was determined as reported earlier by Zhuang et al. [22] with slight modifications. In this assay, different concentrations of extracts $(2-10 \mathrm{mg} / \mathrm{mL})$ were mixed with $3.5 \mathrm{~mL}$ phosphate buffer $(0.2 \mathrm{M}, \mathrm{pH} 6.6)$ and $2 \mathrm{~mL}$ of $1 \%$ potassium ferricyanide. For $20 \mathrm{~min}$, the mixture was incubated at room temperature. Following the addition of 2.5 $\mathrm{mL}$ of $10 \%$ TCA (trichloroacetic acid) the mixture and the mixture was centrifuged for $10 \mathrm{~min}$ at $3000 \mathrm{rpm} .2 .5 \mathrm{~mL}$ of supernatant was collected by pipette and mixed with 2.5 $\mathrm{mL}$ of distilled water. To this mixture 0.5 $\mathrm{mL}$ of $0.1 \%$ ferric chloride was added and then absorbance of the mixture calculated at $700 \mathrm{~nm}$ with a spectrophotometer.

\section{DPPH radical scavenging assay}

The antioxidant activity of Trigonella foenum-graecum was assessed by DPPH (1, 1 diphenyl-2-picrylhydrazyl) radical scavenging assay described by Zhuang et al. [22]. BHA that is synthetic antioxidant was used as a positive control. Calculation was made at $\mathrm{IC}_{50}$, concentration of extract that is scavenged/ neutralized $50 \%$ of DPPH free radicals.

$\mathrm{A}_{\text {control }}=$ the absorbance of control which contain all reagents except sample

$\mathrm{A}_{\text {extract }}=$ the absorbance of extracts

$\%$ scavenging activity $=\left(\mathrm{A}_{\text {control }}-\mathrm{A}_{\text {extract }}\right) / \mathrm{A}_{\text {control }}{ }^{*} 100$ The $\%$ scavenging activity at $50 \%$ is $\mathrm{IC}_{50}$

\section{High performance liquid} chromatography (HPLC) analysis

Individual phenolics profile was analyzed by using HPLC. Separation of phenolic acids was carried out on HPLC using ODS (C18) reversed phase column $(250 \times 4.6 \mathrm{~mm})$ [23] The mobile phase used was acidified acetonitrile $(99.5 \%)$ at a constant flow rate of $1 \mathrm{~mL} / \mathrm{min}$ in isocratic mode. With the help of a microsyringe $20-\mu \mathrm{L}$ sample was injected into the column. The detection was 
carried out at $280 \mathrm{~nm}$. Phenolics compounds were identified by matching their relative retention times with those of the pure standards of targeted compounds. On the basis of peak area measurement, the contents of an individual compounds were calculated.

\section{Antibacterial activity}

The Antibacterial activity of the extracts was determined by disc diffusion method. Nutrient agar medium was prepared and autoclaved. $100 \mu \mathrm{L}$ inoculums was added in medium while it was liquid and cool, mixed and then poured into petri plates. After that $6 \mathrm{~mm}$ wicks paper discs were laid flat on medium and $100 \mathrm{uL}$ extract was put on each disc. For $24 \mathrm{~h}$, the petri plates were then incubated at $37 \mathrm{C}^{\circ}$ to check the growth of bacteria. The extracts showing the antibacterial activity inhibited the bacterial growth by forming clear zone of inhibition, measured in millimeters [24]. The bacterial strains that used were Bacilus Substilis, Streptococcus aureus, Salmonella typahe and E.coli. Ciprofloxacin was used as standard.

\section{Statistical analysis}

Statistical analysis data was expressed as mean values at $95 \%$ confidence interval. Analysis of variance was performed using ANOVA procedures. Significance difference for values with respect to means of samples and solvents were determined. P> 0.05 means no significance difference.
Analysis was done by using SPPS 20 software [25].

\section{Results and discussion Extraction yields}

The extraction yields for antioxidant components from different commercial brands of fenugreek with different solvent systems include methanol $(100 \%, 80 \%$ and $50 \%)$ and chloroform $(100 \%, 80 \%$, and 50 $\%)$. The extract yields ranged from 35.53$62.77 \%$. Maximum yield was obtained from $100 \%$ local methanol while minimum is obtained from $100 \%$ local chloroform. The range from different commercial brands varies like for shan 37.27-55.20, national 37.33-62.40, and local 35.53-62.77. Based on the results, the extraction efficacy of different solvents is $100 \%$ methanol > $0 \%$ methanol > 50\% methanol > $80 \%$ chloroform > 50\% chloroform >100\% chloroform. The higher yield from local $100 \%$ methanol showed that methanol has greater efficacy to recover antioxidant components from commercial brands of fenugreek. Results showed that effect of different solvents and sample type on $(\mathrm{p}<0.05) \%$ extraction yield is significant. So it can be considered that there is a significant difference $(\mathrm{p}<0.05)$ in the extracted yields in relation to the solvent system and fenugreek different commercial brands that has been used. The present result has shown greater yield with methanol (Table 1) that is comparable to [26].

Table 1. Extract yields (\%) of fenugreek

\begin{tabular}{|l|l|l|c|c|}
\hline Solvents & $\begin{array}{l}\text { \% Composition } \\
\text { of solvents }\end{array}$ & \multicolumn{3}{|c|}{ Yield (\%) } \\
\cline { 2 - 5 } & $100 \%$ & Shan & National & Local \\
\hline \multirow{3}{*}{ Chloroform } & $80 \%$ & $37.27 \pm 1.05^{\mathrm{A}}{ }_{\mathrm{a}}$ & $37.33 \pm 0.05^{\mathrm{B}}{ }_{\mathrm{a}}$ & $35.53 \pm 0.15^{\mathrm{B}}{ }_{\mathrm{a}}$ \\
\cline { 2 - 5 } & $50 \%$ & $44.66 \pm 1.39^{\mathrm{A}} \mathrm{b}$ & $38.47 \pm 0.35^{\mathrm{B}}{ }_{\mathrm{b}}$ & $39.40 \pm 0.26^{\mathrm{B}}{ }_{\mathrm{b}}$ \\
\hline \multirow{3}{*}{ Methanol } & $100 \%$ & $38.60 \pm 0.95^{\mathrm{A}}{ }_{\mathrm{a}}$ & $42.46 \pm 1.10^{\mathrm{B}}{ }_{\mathrm{a}}$ & $40.46 \pm 0.35^{\mathrm{B}}{ }_{\mathrm{a}}$ \\
\cline { 2 - 5 } & $80 \%$ & $55.20 \pm 1.00^{\mathrm{A}}{ }_{\mathrm{c}}$ & $62.40 \pm 0.26^{\mathrm{B}}{ }_{\mathrm{c}}$ & $62.77 \pm 0.94^{\mathrm{B}}$ \\
\cline { 2 - 5 } & $50 \%$ & $54.20 \pm 0.10^{\mathrm{A}}{ }_{\mathrm{d}}$ & $55.37 \pm 0.15$ & $55.60 \pm 0.10^{\mathrm{B}}{ }_{\mathrm{d}}$ \\
\hline
\end{tabular}

Values are means \pm SD $(n=3)$ of three separate experiments. Different small letter in subscript within the same column show significant $(p<0.05)$ differences of means among Citrus species. Different superscript letters within the same row show significant $(p<0.05)$ differences of means among extraction solvents 


\section{Total phenolic contents}

Total phenolic contents from different brands of fenugreek (Shan, National, Local) by using different solvents $(100 \%, 80 \%$, $50 \%$ methanol and $100 \%, 80 \%, 50 \%$ chloroform) ranged from 27.8-42.60 \% of dry weight (DW). The lowest value observed was $27.8 \%$ for national $50 \%$ chloroform and highest value was for shan $100 \%$ methanol $(42.60 \mathrm{~g} / 100 \mathrm{~g})$. Different TPC values have been observed from different brands of fenugreek like shan 27.842.60, national 25.0-41.2 and local 24.440.1. The order of TPC by using different solvents was $100 \%$ methanol > $80 \%$ methanol $>50 \%$ methanol $>100 \%$ chloroform > $>80 \%$ chloroform $>50 \%$ chloroform. The present trend of solvent trend showing higher yields in methanol (Methanol has a polarity index of 5.1. Mostly methanol is used for extraction various polar compounds but certain group of non-polar compounds are fairly soluble in methanol if not readily soluble) is comparable to Birjees et al. [27]. Leena et al. [28] also reported the highest TPC content in methanol followed by chloroform. The values were observed comparatively higher as compare to the present trend. Other factors that contribute to the recovery of phenolic contents may include polarity and solubility of compounds and solvents as well. TPC that has been observed from different fenugreek brands was found to be in order of local $<$ national $<$ shan $($ Table 2 ).

Table 2. Total phenolic and flavonoid contents of extracts from fenugreek

\begin{tabular}{|c|c|c|c|c|c|c|}
\hline \multirow[t]{2}{*}{ Solvents } & \multicolumn{3}{|c|}{ TPC (GAE mg/g DW) } & \multicolumn{3}{|c|}{ TFC (CE mg/g DW) } \\
\hline & Shan & National & Local & Shan & National & Local \\
\hline $100 \%$ & $35.2 \pm 0.00_{\mathrm{a}}^{\mathrm{A}}$ & $34.3 \pm 0.02{ }^{\mathrm{b}}{ }^{\mathrm{A}}$ & $32.1 \pm 0.00^{\mathrm{A}}$ & $1.86 \pm 0.0_{\mathrm{a}}^{\mathrm{A}}$ & $1.86 \pm 0.1_{\mathrm{a}}^{\mathrm{A}}$ & $1.85 \pm 0.02^{\mathrm{a}}$ \\
\hline $80 \%$ chloroform & $33.2 \pm 0.01_{\mathrm{a}}^{\mathrm{B}}$ & $32.3 \pm 0.02_{b}{ }^{B}$ & $31.9 \pm 0.02^{{ }^{B}}$ & $1.85 \pm 0.0_{\mathrm{a}}^{\mathrm{B}}$ & $0.91 \pm 0.0_{\mathrm{a}}^{\mathrm{B}}$ & $1.7 \pm 0.1_{\mathrm{a}}^{\mathrm{B}}$ \\
\hline $50 \%$ chloro & $27.8 \pm 0.05_{\mathrm{a}}^{\mathrm{A}}$ & $25.0 \pm 0.01_{\mathrm{b}}^{\mathrm{A}}$ & $24.4 \pm 0.03^{\mathrm{A}}$ & $0.87 \pm 0.0_{\mathrm{a}}^{\mathrm{C}}$ & $0.75 \pm 0.1_{\mathrm{a}}{ }^{\mathrm{C}}$ & $1.31 \pm 0.59^{\mathrm{C}}$ \\
\hline $100 \%$ methanol & $42.60 \pm 0.04 \mathrm{a}^{\mathrm{D}}$ & $41.2 \pm 0.01_{b} \mathrm{D}$ & $40.1 \pm 0.06^{\mathrm{D}}$ & $1.22 \pm 0.0_{\mathrm{a}}^{\mathrm{B}}$ & $1.74 \pm 0.1_{\mathrm{a}^{\mathrm{B}}}^{\mathrm{B}}$ & $0.96 \pm 0.1_{\mathrm{a}}^{\mathrm{B}}$ \\
\hline $80 \%$ methanol & $40.5 \pm 0.03_{a^{\mathrm{E}}}$ & $41 \pm 0.04_{b}{ }^{\mathrm{E}}$ & $39.9 \pm 0.11_{\mathrm{a}}^{\mathrm{E}}$ & $1.87 \pm 0.0_{\mathrm{a}}^{\mathrm{A}}$ & $1.75 \pm 0.1_{\mathrm{a}}^{\mathrm{A}}$ & $1.77 \pm 0.0_{\mathrm{a}}^{\mathrm{A}}$ \\
\hline $50 \%$ methanol & $38.4 \pm 0.03^{\mathrm{F}}$ & $36 \pm 0.04_{b}{ }^{F}$ & $37.1 \pm 0.07_{\mathrm{a}}^{\mathrm{F}}$ & $1.65 \pm 0.3_{\mathrm{a}}^{\mathrm{B}}$ & $1.78 \pm .47_{\mathrm{a}}^{\mathrm{B}}$ & $1.46 \pm 0.03^{\mathrm{a}}$ \\
\hline
\end{tabular}

Values are means \pm SD $(n=3)$ of three separate experiments. Different small letter in subscript within the same column show significant $(p<0.05)$ differences of means among Citrus species. Different superscript letters within the same row show significant $(p<0.05)$ differences of means among extraction solvents.

\section{Total flavonoid contents (TFC)}

Total Flavonoid contents (TFC) observed in different commercial brands of fenugreek is given in Table 2. Values of TFC extracted from different brands of fenugreek ranged from $0.75-1.87 \mathrm{CE} \mathrm{mg/g}$ of dry weight. The maximum value was observed with $80 \%$ methanol from shan and lowest value observed from $50 \%$ chloroform national. The value from different commercial brands of fenugreek extracts were shan 0.87-1.87, national 0.75-1.86, local 0.96-1.85. The order of solvents ability for TFC extraction was $100 \%$ chloroform $>80 \%$ methanol > $50 \%$ methanol > $80 \%$ chloroform> $100 \%$ methanol> $50 \%$ chloroform. The order of TFC values of commercial brands of fenugreek was shan > national > local. TFC values varied prominently among different commercial brands of fenugreek. The present values of TFC are comparable to the values that were observed by Leena et al. [28] and Birjees et al. [27], results of TFC observed in case of methanol were quite higher as compare to the present values.

\section{DPPH radical scavenging activity}

IC50 (In term of DPPH scavenging activity) for different commercial brands of fenugreek ranged from $0.927-3.78 \mathrm{mg} / \mathrm{mL}$ shown in Table 3. The highest value was 
noted for local $80 \%$ chloroform 3.78 , while lowest value was observed in case of Shan $100 \%$ chloroform Table 3. IC50 ( $\mathrm{mg} / \mathrm{ml})$ values for different commercial brands of fenugreek varied significantly with respect to the solvents that has been used. $80 \%$ local chloroform considered to be on the higher range comparatively. Collectively, the order of solvents for antioxidant potential is $50 \%$ methanol $>80 \%$ methanol $>80 \%$ chloroform > $100 \%$ methanol> $50 \%$ chloroform $>100 \%$ chloroform. The effect of extraction solvents on radical scavenging activity is significant $(p<0.05)$. The order of commercial brands of fenugreek to scavenge the free radical is local > national > shan. Local Fenugreek has shown highest radical scavenging activity showing significant $(p<0.05)$ variations among other commercial brands. Anupma et al. [29] observed highest radical scavenging activity in methanol which is comparable to the present trend.

Table 3. DPPH radical scavenging activity and reducing power

\begin{tabular}{|c|c|c|c|c|c|c|}
\hline \multirow[t]{2}{*}{ Solvents } & \multicolumn{3}{|c|}{ DPPH $\left(I_{50} \mathrm{mg} / \mathrm{mL}\right)$} & \multicolumn{3}{|c|}{ Reducing power $\left(\mathrm{EC}_{50} \mathrm{mg} / \mathrm{mL}\right)$} \\
\hline & Shan & National & Local & Shan & National & Local \\
\hline $100 \%$ & $0.927 \pm 0.05_{\mathrm{a}}^{\mathrm{A}}$ & $1.91 \pm 0.00_{\mathbf{b}}{ }^{\mathrm{A}}$ & $1.87 \pm 0.03_{\mathrm{c}^{\mathrm{A}}}^{\mathrm{A}}$ & $7.76 \pm 0.05_{\mathrm{a}}^{\mathrm{A}}$ & $6.37 \pm 0.04_{\mathrm{a}}^{\mathrm{A}}$ & $5.51 \pm 0.03_{\mathrm{a}}^{\mathrm{A}}$ \\
\hline $80 \% \mathrm{c}$ & $1.66 \pm 0.03_{\mathrm{a}}^{\mathrm{B}}$ & $2.87 \pm 0.07_{b^{B}}$ & $3.78 \pm 0.06^{\mathrm{B}}$ & $6.49 \pm 0.00_{\mathrm{a}}^{\mathrm{A}}$ & $6.19 \pm 0.02_{\mathrm{a}}^{\mathrm{A}}$ & $6.56 \pm 0.67 \mathrm{a}^{\mathrm{A}}$ \\
\hline $50 \% \mathrm{cl}$ & $2.82 \pm 0.83_{\mathrm{a}^{\mathrm{B}}}^{\mathrm{B}}$ & $2.5 \pm 0.01_{\mathrm{b}}^{\mathrm{B}}$ & $2.07 \pm 0.02_{\mathrm{c}^{\mathrm{B}}}^{\mathrm{B}}$ & $5.09 \pm 0.00_{\mathrm{a}}^{\mathrm{B}}$ & $6.08 \pm 0.04_{\mathrm{a}}^{\mathrm{B}}$ & $6.13 \pm 0.03_{\mathrm{a}}^{\mathrm{B}}$ \\
\hline $100 \%$ met & $2.03 \pm 0.04{ }^{\mathrm{C}}$ & $2.46 \pm 0.05_{b} \mathrm{C}$ & $2.46 \pm 0.03_{\mathrm{c}}^{\mathrm{C}}$ & $5.04 \pm 0.00_{\mathrm{a}}^{\mathrm{C}}$ & $4.20 \pm 0.00_{\mathrm{a}}^{\mathrm{C}}$ & $5.35 \pm 0.02_{\mathrm{a}}^{\mathrm{C}}$ \\
\hline $80 \%$ methanol & $2.23 \pm 0.20_{\mathrm{a}}^{\mathrm{B}}$ & $2.34 \pm 0.05_{b}{ }^{B}$ & $3.21 \pm 0.2^{\mathrm{B}}$ & $6.13 \pm 0.00_{\mathrm{a}}^{\mathrm{A}}$ & $5.04 \pm 0.04 \mathrm{a}^{\mathrm{A}}$ & $7.24 \pm 0.07 \mathrm{a}^{\mathrm{A}}$ \\
\hline $50 \%$ methanol & $2.68 \pm 0.01_{\mathrm{a}}^{\mathrm{B}}$ & $3.45 \pm 0.49^{b}$ & $2.67 \pm 0.04_{c}^{\mathrm{B}}$ & $6.41 \pm 0.02_{\mathrm{a}}^{\mathrm{A}}$ & $6.34 \pm 0.01_{\mathrm{a}}^{\mathrm{A}}$ & $7.24 \pm 0.07 \mathrm{a}^{\mathrm{A}}$ \\
\hline
\end{tabular}

Values are means \pm SD $(n=3)$ of three separate experiments. Different small letter in subscript within the same column show significant $(p<0.05)$ differences of means among Citrus species. Different superscript letters within the same row show significant $(p<0.05)$ differences of means among extraction solvents

\section{Reducing power}

The $\mathrm{EC}_{50}$ for different commercial brands of fenugreek is given in (Table 3). The $\mathrm{EC}_{50}$ values ranged from 4.20-7.76. The lowest value has been observed in $100 \%$ methanol national and highest value has been observed in chloroform $100 \%$ (7.76). The $\mathrm{IC}_{50}$ values for commercial brands of fenugreek are shan 5.04-7.76, national 4.206.37 and local 5.35-7.24 The ability to extract solvents in order to recover the reducing agent from commercial brand of fenugreek is in order of $50 \%$ methanol > $100 \%$ chloroform $>80 \%$ chloroform $>80 \%$ methanol > 50\% chloroform $>100 \%$ methanol. The reducing potential for commercial brand of fenugreek is shan > local > national. According to Bukhari et al. [30] methanol extract of fenugreek show higher value that is comparable to the present work.

\section{Phenolic acids profile}

With the help of HPLC, qualitative and quantitative analysis of phenolic acid is performed. Comparison has been made between commercial brands of fenugreek and standard phenolic acids. Ten phenolic acids have been used that include gallic acid, caffic acid, chlorogenic acid, protocatechuic acid, 3-hydroxy benzoic acid, syringic acid, 4-hydroxyl benzoic acid, p-coumeric acid, 3,5 dihydroxyl benzoic acid and vanillic acid. Total phenolic acids were ranged between 18.36-1035.99. The range of gallic acid and protocatechuic acid is 10.90-96.89 $\mathrm{mg} / \mathrm{kg}$ and $2441-277.70 \mathrm{mg} / \mathrm{kg}$ of extract respectively. Gallic acid was present in almost all the samples except few ones. The highest value of gallic acid was found in $100 \%$ methanol (shan 96.89) and lowest value was found in $50 \%$ chloroform (national 10.90). Higher amount of all present phenolic acids was found in shan $80 \%(275.70 \mathrm{mg} / \mathrm{kg})$ as shown in Table 4. 
These phenolic acids play a great role as antioxidant and has a great medicinal value. Gallic acid is found in a frequent amount that can easily be absorbed by human body and it has a positive influence on the canserious cell and prevent their growth. Pcoumaric acid plays a significant role in prevention of stomach cancer by inhibiting the activity of carcinogenic nitrosamines [31].

\section{Biological activity}

Fenugreek (Trigonella foenum-graecum) has antibacterial activity which was tested against different bacterial strains like Bacilus Substilis, Streptococcus aureus, Salmonella typahe and Escherichia-coli (Table 5 and 6).

For Bacilus Substilis, values of antibacterial activity for different commercial fenugreek brands were ranged from 10.47-24.30 mm. The maximum value was observed for methanol 100\% (24.30 mm) extract. While minimum value was observed for chloroform $(10.77 \mathrm{~mm})$. The antibacterial values of different samples include shan fenugreek (10.77-24.30), national fenugreek (11.37-23.33), and local fenugreek (10.4723.30). Values of antibacterial activity against $E$. coli ranged from $10.43-24.27 \mathrm{~mm}$. - The maximum value was observed for methanol $100 \%$ shan $(24.30 \mathrm{~mm})$ extract.
While minimum value was observed for chloroform $50 \%$ (10.77mm) local. The antibacterial values of different samples include shan (11.43-24.27), national (11.3723.47) and local (10.43-23.30).

Maximum antibacterial activity against Staphlococus aureus was observed for methanol 100\% Shan $(23.17 \mathrm{~mm})$ extract. While minimum value was observed for chloroform $50 \%$ National $(10.23 \mathrm{~mm})$. The antibacterial values of different samples include Shan (10.40-23.17), National (10.23-22.37), and Local (10.40-21.40). $80 \%$ methanol Local extract was found to be on top rank related to antibacterial activity against Salmonella tyaphimurium. While minimum value was observed for chloroform 50\% National $(10.23 \mathrm{~mm})$. The antibacterial values of different samples include shan (10.40-23.17), national (10.3723.50) and local (10.37-26.48).

Collectively, the order of solvents used for antibacterial activity against selected bacterial strain is: $100 \%$ methano $1>100 \%$ chloroform > $80 \%$ methanol > $80 \%$ chloroform > 50\% methanol > $50 \%$ chloroform showing significant effect $(p<0.05)$. The results are also comparable to those reported by Mehmood et al. [31] fenugreek (Trigonella foenum-graecum) has an antibacterial activity. 
Table 4. Individual phenolic acids ( $\mathrm{mg} / \mathrm{kg}$ of extract) profile Trigonella foenum-graecum) of extracts from different commercial brands of fenugreek

\begin{tabular}{|c|c|c|c|c|c|c|c|c|c|c|c|c|}
\hline \multirow[t]{2}{*}{ Extracts } & \multirow[t]{2}{*}{ samples } & \multicolumn{10}{|c|}{ Phenolic Acids (mg/kg) } & \multirow[t]{2}{*}{$\begin{array}{l}\text { Total amount } \\
\text { of phenolic } \\
\text { acids }(\mathrm{mg} / \mathrm{kg})\end{array}$} \\
\hline & & $\begin{array}{l}\text { Gallic } \\
\text { acid }\end{array}$ & $\begin{array}{l}\text { Caffic } \\
\text { acid }\end{array}$ & $\begin{array}{l}\text { Chloro } \\
\text { genic } \\
\text { acid }\end{array}$ & $\begin{array}{l}\text { Proto } \\
\text { catechuic } \\
\text { acid }\end{array}$ & $\begin{array}{l}\text { 3-hydroxy } \\
\text { benzoic } \\
\text { acid }\end{array}$ & Catechin & $\begin{array}{l}\text { 4-hydroxyl } \\
\text { benzoic } \\
\text { acid }\end{array}$ & $\begin{array}{l}\rho \text {-coumaric } \\
\text { acid }\end{array}$ & $\begin{array}{l}3,5 \\
\text { dihydroxyl } \\
\text { benzoic } \\
\text { acid } \\
\end{array}$ & $\begin{array}{l}\text { Ferulic } \\
\text { acid }\end{array}$ & \\
\hline \multirow{3}{*}{$\begin{array}{l}100 \% \\
\text { Chloroform }\end{array}$} & Shan & 91.89 & 87.22 & $\ldots$ & & _- & 5.5 & _ & _ & - & $\ldots$ & 184.61 \\
\hline & National & 19.53 & 87.71 & 61.9 & - & _- & - & _ & - & _ & - & 169.14 \\
\hline & Local & 18.36 & - & - & _ & _- & - & _- & - & _- & - & 18.36 \\
\hline \multirow{3}{*}{$\begin{array}{l}80 \% \\
\text { Chloroform }\end{array}$} & Shan & 13.05 & 744.24 & $\ldots$ & 277.70 & _ & _ & - & - & - & _ & 1035.44 \\
\hline & National & 63.48 & 39.65 & - & & & & & _ & _ & _ & 103.13 \\
\hline & Local & 22.72 & & - & 244.15 & & 125.78 & - & - & - & - & 392.65 \\
\hline \multirow{3}{*}{$\begin{array}{l}\mathbf{5 0 \%} \\
\text { Chloroform }\end{array}$} & Shan & 76.98 & $\ldots$ & $\ldots$ & - & $\ldots$ & _ & _ & - & 183.84 & 288.79 & 549.61 \\
\hline & National & 10.90 & $\ldots$ & 105.14 & - & _- & 122.77 & - & - & - & - & 238.81 \\
\hline & Local & 23.02 & - & - & - & - & - & - & - & - & - & 23.02 \\
\hline \multirow{3}{*}{$\begin{array}{l}100 \% \\
\text { Methanol }\end{array}$} & Shan & 96.89 & 88.22 & 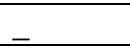 & & $\ldots$ & 6.5 & _ & - & - & $\ldots$ & 191.61 \\
\hline & National & 19.53 & 85.71 & 62.9 & - & _ & - & - & - & - & - & 168.14 \\
\hline & Local & 14.36 & - & - & _ & - & _ & - & - & - & - & 14.36 \\
\hline \multirow{3}{*}{$\begin{array}{l}80 \% \\
\text { Methanol }\end{array}$} & Shan & 14.05 & 764.24 & - & 275.70 & _- & $\ldots$ & $\ldots$ & - & - & - & 1035.99 \\
\hline & National & 64.48 & 38.65 & - & & & & & - & _ & - & 103.13 \\
\hline & Local & 23.72 & & - & 245.15 & & 126.78 & - & - & - & - & 395.65 \\
\hline \multirow{3}{*}{$\begin{array}{l}50 \% \\
\text { Methanol }\end{array}$} & Shan & 77.98 & - & $\ldots$ & - & _ & - & _ & - & 184.84 & 287.79 & 550.61 \\
\hline & National & 12.90 & - & 107.14 & - & - & 125.77 & - & - & - & - & 245.81 \\
\hline & Local & 24.02 & - & - & - & - & - & - & - & - & - & 24.02 \\
\hline
\end{tabular}


Table 5. Antibacterial activity of different commercial brands of fenugreek (Trigonella foenum graecum) against Escherichia coli and Bacillus subtilis

\begin{tabular}{|c|c|c|c|c|c|c|}
\hline \multirow[t]{2}{*}{ Solvents } & \multicolumn{3}{|c|}{$\begin{array}{l}\text { Zone of inhibition (mm) against } \\
\text { Escherichia coli }\end{array}$} & \multicolumn{3}{|c|}{$\begin{array}{l}\text { Zone of inhibition (mm) against Bacillus } \\
\text { subtilis }\end{array}$} \\
\hline & Shan & National & Local & Shan & National & Local \\
\hline $100^{c}$ & $21.83 \pm 0.76^{\mathrm{A}}{ }_{a}$ & $21.47 \pm 0.45^{\mathrm{B}}$ & $22.23 \pm 0.21_{\mathrm{a}}^{\mathrm{C}}$ & $21.13 \pm 0.15^{\mathrm{A}}$ & $21.23 \pm 0.21_{\mathrm{a}}^{\mathrm{A}}$ & $22.27 \pm 0.25^{\mathrm{A}}$ \\
\hline $80 \% \mathrm{c}$ & $13.3 \pm 0.32^{\mathrm{A}} \mathrm{b}$ & $13.43 \pm 0.37^{\mathrm{B}}{ }_{b}$ & $12.53 \pm 0.47_{b}^{C_{b}}$ & $12.37 \pm 0.32^{\mathrm{A}} \mathrm{b}$ & $12.47 \pm 0.42^{\mathrm{A}} \mathrm{b}$ & $12.50 \pm 0.43^{\mathrm{A}} \mathrm{b}$ \\
\hline $50 \%$ chloroform & $11.43 \pm 0.37_{c}^{\mathrm{A}}$ & $11.37 \pm 0.35^{\mathrm{B}}{ }_{\mathrm{c}}$ & $10.43 \pm 0.37_{c}^{\mathrm{C}}$ & $10.77 \pm 0.80_{c}^{\mathrm{A}_{c}}$ & $11.37 \pm 0.35^{\mathrm{A}_{\mathrm{c}}}$ & $10.47 \pm 0.42^{\mathrm{A}}{ }_{c}$ \\
\hline $100 \%$ & $24.27 \pm 0.25^{\mathrm{A}}{ }_{\mathrm{d}}$ & $23.47 \pm 0.45^{\mathrm{B}}{ }_{\mathrm{d}}$ & $23.30 \pm 0.26^{\mathrm{C}}{ }_{\mathrm{d}}$ & $24.30 \pm 0.26^{\mathrm{A}}$ & $23.33 \pm 0.31^{\mathrm{A}}$ & $23.30 \pm 0.26^{\mathrm{A}}$ \\
\hline $80 \% \mathrm{~m}$ & $17.37 \pm 0.32^{\mathrm{A}} \mathrm{e}_{\mathrm{e}}$ & $16.30 \pm 0.30^{\mathrm{B}}$ & $15.48 \pm 0.42^{\mathrm{C}}{ }_{\mathrm{e}}$ & $17.33 \pm 1.70_{\mathrm{e}}^{\mathrm{A}}$ & $17.30 \pm 0.30^{\mathrm{A}} \mathrm{e}_{\mathrm{e}}$ & $16.48 \pm 0.42^{\mathrm{A}}$ \\
\hline $50 \% 1$ & $12.33 \pm 0.30_{f}^{A_{f}}$ & & $11.33 \pm 0.35^{C_{f}}$ & $13.33 \pm 0.31_{\mathrm{f}}^{\mathrm{A}_{\mathrm{f}}}$ & & $11.05 \pm 0.25_{\mathrm{f}}^{\mathrm{A}}$ \\
\hline Ciprofloxacin & $10.3 \pm 0.23 \mathrm{~A}$ & $10.3 \pm 0.23 \mathrm{~B}$ & $10.3 \pm 0.23 \mathrm{C}$ & $14.3 \pm 0.32 \mathrm{~A}$ & $14.3 \pm 0.32 \mathrm{~B}$ & $14.3 \pm 0.32 \mathrm{C}$ \\
\hline
\end{tabular}

Values are means \pm SD $(n=3)$ of three separate experiments. Different small letter in subscript within the same column show significant $(p<0.05)$ differences of means among Citrus species. Different superscript letters within the same row show significant $(p<0.05)$ differences of means among extraction solvents

Table 6. Antibacterial activity of different commercial brands of fenugreek (Trigonella foenum-graecum) against Salmonella tyaphimurium and Staphlococus aureus

\begin{tabular}{|c|c|c|c|c|c|c|}
\hline \multirow[t]{2}{*}{ Solvents } & \multicolumn{3}{|c|}{$\begin{array}{l}\text { Zone of inhibition (mm) against Salmonella } \\
\text { tyaphimurium }\end{array}$} & \multicolumn{3}{|c|}{$\begin{array}{l}\text { Zone of inhibition (mm) against } \\
\text { Staphlococus aureus }\end{array}$} \\
\hline & Shan & National & Local & Shan & National & Local \\
\hline $100 \%$ chloroform & $21.40 \pm 0.36^{\mathrm{A}}{ }_{\mathrm{a}}$ & $21.40 \pm 0.40_{\mathrm{a}}^{\mathrm{B}}$ & $21.23 \pm 0.21_{\mathrm{a}}^{\mathrm{A}}$ & $21.17 \pm 0.15^{\mathrm{A}}{ }_{\mathrm{a}}$ & $22.33 \pm 0.31_{a}^{\mathrm{A}}$ & $21.40 \pm 0.36_{\mathrm{a}}^{\mathrm{B}}$ \\
\hline $80 \% \mathrm{c}$ & $14.37 \pm 0.32^{\mathrm{A}}$ & $14.43 \pm 0.38^{\mathrm{B}_{\mathrm{b}}}$ & $14.53 \pm 14.53_{b}^{\mathrm{A}}$ & $14.16 \pm 0.15^{\mathrm{A}}$ & $14.40 \pm 0.36_{\mathrm{b}}^{\mathrm{A}}$ & $14.37 \pm 0.30^{B_{b}}$ \\
\hline $50 \% \mathrm{cl}$ & $10.4 \pm 0.38 \mathrm{~A}_{\mathrm{c}}$ & $10.37 \pm 0.3_{c}^{\mathrm{B}}$ & $10.37 \pm 10.37^{\mathrm{A}}$ & $10.40 \pm 0.24_{c}^{A_{c}}$ & $10.23 \pm 0.21_{c}^{A_{c}}$ & $10.40 \pm 0.40^{\mathrm{B}}{ }_{\mathrm{c}}$ \\
\hline $100 \%$ & $23.27 \pm 0.35^{\mathrm{A}_{\mathrm{d}}}$ & $23.50 \pm 0.44^{\mathrm{B}}{ }_{\mathrm{d}}$ & $23.30 \pm 23.30^{A_{d}}$ & $23.17 \pm 0.15^{A_{d}}$ & $22.37 \pm 0.32 \mathrm{~A}_{\mathrm{d}}$ & $21.40 \pm 0.36^{\mathrm{B}}$ \\
\hline $80 \% \mathrm{~m}$ & $16.37 \pm 0.32^{\mathrm{A}}{ }_{\mathrm{e}}$ & $16.37 \pm 0.35^{\mathrm{B}}$ & $26.48 \pm 26.48_{\mathrm{e}}^{\mathrm{A}}$ & $15.17 \pm 0.15^{\mathrm{A}}$ & $15.4 \pm 0.36^{\mathrm{A}}{ }_{\mathrm{e}}$ & $14.37 \pm 0.32^{\mathrm{B}}$ \\
\hline $50 \%$ & $11.33 \pm 0.31_{\mathrm{f}}^{\mathrm{A}_{\mathrm{f}}}$ & $11.40 \pm 0.40_{\mathrm{f}}^{\mathrm{B}_{\mathrm{f}}}$ & $11.43 \pm 11.43_{\mathrm{f}}^{\mathrm{A}_{\mathrm{f}}}$ & $10.40 \pm 0.36_{\mathrm{f}}^{\mathrm{A}_{\mathrm{f}}}$ & $10.3 \pm 0.26^{A_{f}}$ & $10.43 \pm 0.40_{\mathrm{f}}^{\mathrm{B}_{\mathrm{f}}}$ \\
\hline Ciprofloxacin & $9.3 \pm 0.31$ & $9.3 \pm 0.31$ & $9.3 \pm 0.31$ & $9.3 \pm 0.31$ & $9.3 \pm 0.31$ & $9.3 \pm 0.31$ \\
\hline
\end{tabular}

Values are means $\pm \mathrm{SD}(\mathrm{n}=3)$ of three separate experiments. Different small letter in subscript within the same column show significant $(p<0.05)$ differences of means among Citrus species. Different superscript letters within the same row show significant $(p<0.05)$ differences of means among extraction solvents

\section{Conclusion}

It can be concluded that each commercial brand of fenugreek contain a considerable amount of antioxidants. Solvents have a significant role in the extraction of plant constituents. The phenolics and total flavonoid contents were extracted in moderate to high yields. The higher yield of $100 \%$ methanol showed that, it has greater efficiency to recover antioxidant components from commercial brands of fenugreek as compared to the extract of chloroform. Extracts from all tested brands contain considerable antimicrobial activity against microorganisms like $S$. typhae, $S$. aureus, E. coli and B. substili. Above parameter elucidated that different commercial brands of fenugreeks have good antioxidant potential and substantial contents of phenolics so, our findings suggest, it can be used as a natural source powerful antioxidants and preservatives in food industry and pharmaceuticals .

\section{Authors' contributions}

Conceived and designed the experiments: $\mathrm{T}$ Mehmood, Performed the Experiments: M Ahmed \& Z Jabeen, Analyzed the Data: T Mehmood, A Karim, MA Shaheen \& F Siddique, Contributed reagents/ materials/ analysis tools: T Mehmood. Wrote the paper: T Mehmood \& F Siddique. 


\section{References}

1. Niwa T, Doi U, Kato $Y$ \& Osawa $T$ (2001). Antioxidant properties of phenolic antioxidants isolated from corn steep liquor. J Agri Food Chem 49: 177182.

2. Bergman M, Varshavsky L, Gottlieb H \& Grossman S (2001). The antioxidant activity of aqueous spinach extract: chemical identification of active fraction. Phytochem 58: 143-152.

3. Anwar F, Jamil A, Iqbal I \& Sheikh A (2006). Antioxidant activity of various plant extracts under ambient and accelerated storage of sunflower oil. Grasas Y Aceites 57: 189-197.

4. Anwar F, Naseer R, Bhanger M, Ashraf S, Talpor F \& Aladedunye F (2008). Physico-chemical characteristics of Citrus seeds and seed oils from Pakistan. $J$ Am Oil Chem Soc 85: 321-330.

5. Karoui J \& Marzouk B (2013). Characterization of bioactive compounds in Tunisian bitter orange (Citrus aurantium L.,) peel and juice and determination of their antioxidant activities. Bio Med Res Int 1-12.

6. Maestri D, Nepote V, Lamarque A \& Zygadlo J (2006). Natural products as antioxidants. Phytochem: Adv Res 105135.

7. Dimitios B (2006). Sources of natural phenolic antioxidants. Trends Food Sci Technol 17: 505-512.

8. Sánchez-Salcedo E, Mena P, GarcíaViguera C, Hernández F \& Martínez J (2015). (Poly) phenolic compounds and antioxidant activity of white (morus alba) and black (morus nigra) mulberry leaves: their potential for new products rich in phytochemicals. $J$ functional foods 18 : 1039-1046.

9. Venkatesh K \& Chauhan S (2008). Mulberry Life enhancer. J Med Plants Res 2: 271-278.
10. Raju J, Gupta D, Rao A, Yadava P \& Baquer N (2001). Trigonella foenum graecum (fenugreek) seed powder improves glucose homeostasis in alloxan diabetic rat tissues by reversing the altered glycolytic, gluconeogenic and lipogenic enzymes. Mol Cell Biochem 224: 45-51.

11. Alemua A \& Doepel L (2011). Fenugreek (Trigonella foenum-graecum L.) as alternative forage for dairy cows. Animal 9: 1370-1381.

12. Basch E, Ulbricht C, Kuo G, Szapary P, Smith M \& Pharm S (2003). Therapeutic Applications of Fenugreek. Alternat Med 8: 20-27.

13. Balasundram N, Sundram K \& Samman S (2006). Phenolic compounds in plants and agri-industrial by-products: Antioxidant activity, occurrence, and potential uses. Food Chem 99: 191-203.

14. Abdel-Massih R, Abdou E, Baydoun E \& Daoud Z (2010). Antibacterial Activity of the Extracts Obtained from Rosmarinus officinalis, Origanum majorana, and Trigonella foenumgraecum on Highly Drug-Resistant Gram Negative Bacilli. J Bot 47: 77-85.

15. Kim E, Lee J \& Choi S (2006). Quantitative changes in phenolic compounds of safflower (Carthamus tinctorius L.) seeds during growth and processing. J Food Sci Nutr 11: 311317.

16. Lee W \& Choi S (2012). Quantitative changes of polyphenolic compounds in mulberry (Morus alba L.) leaves in relation to varieties, harvest period, and heat processing. Prev Nutr Food Sci 17: 250-258.

17. Thanh V, Christopher J, Michael C, Phuong D \& Quan V (2017). Impact of Different Extraction Solvents on Bioactive Compounds and Antioxidant Capacity from the Root of Salacia chinensis L. J Food Quality 
18. Mehrafarin A, Rezazadeh S, Naghdibadi H, Noormohammadi Z \& Qaderi A (2011). A Review on Biology, Cultivation and BBiotechnology of Fenugreek (Trigonellafoenum-graecum L.) as a Valuable Medicinal Plant and Multipurpose. J plant genetics 10: 6-24.

19. Chatterjee S, Variyar P \& Sharma A (2010). Bioactive lipid constituents of fenugreek. Food Chem 119: 349-353.

20. Kalpna R, Mital K \& Sumitra C (2011). Vegetable and fruit peels as a novel source of antioxidants. $J$ Medicinal plants Res 5: 63-71.

21. Zhishen J, Mengchemg T \& Jianming W (1999). The determination of falvonoid contents in mulberry and their scavenging effects on superoxide radicals. Food Chem 64: 555-559.

22. Zhuang Y, Chen L, Sun L \& Cao J (2012). Bioactive characteristics and antioxidant activities of nine peppers. $J$ Functional Foods 4: 331-338.

23. Petropoulos G (2002). Fenugreek - The genus Trigonella. Taylor and Francis, London and New York 255.

24. Sarpeleh A, Sharifi K \& Sonbolkar A (2009). Evidence of antifungal activity of wild rue (Peganum harmala L.) on phytopathogenic fungi. $J$ Plant Dis Protec 5: 208-213.

25. Steel R, Torrie J \& Dickey T (1997). Principles and Practice of Statistics: A biomedical Approach, McGraw-Hill Companies, Inc. New York.
26. Bharti P, Jahani N, Rahman K \& Asi MR (2013). Phenolic Acid and Flavonol and Flavonol Contents of gemmomodified and Native Extracts of some Indigenous Medical Plants, Pakistan. $J$ Bot 45: 151-1519.

27. Birjees S, Bhanger $M$ \& Memon S (2008). Antioxidative Activity of Extracts from Fenugreek Seeds (Trigonella foenum-graecum., Pak J Ana Env Chem 9: 78-83.

28. Leena S, Siwach P, Bal S, Malik A, Bharti P \& Dalal S (2014). Free Radical Scavenging Activity, Phenolic contents and Phytochemical analysis of seeds of (Trigonella foenum graecum). Asian Pacific J Health Sci 1: 219-226.

29. Anumpa B, Leena S, Siwach P, Bal S, Malik A \& Dalal S (2014). Free Radical Scavenging Activity, Phenolic contents and Phytochemical analysis of seeds of (Trigonella foenum graecum). Asian Pacific J Health Sci 3: 219-226.

30. Bukhari S, Bhanger M \& Shahabuddin M (2008). Antioxidative Activity of Extracts from Fenugreek Seeds (Trigonella foenum-graecum). Pak J Anal Environ Chem 9: 78-83.

31. Mehmood T, Qadeer H, Jabeen Z, Karim A, Shaheen $M$ \& Siddique F (2016). Variation in bioactive compounds, phenolic acids and antibacterial activity of extracts acquiring from fruits of Morus nigra in relation to solvents system. BiologiaPakistan 62(2): 229-239. 